\title{
Polymorphisms of DNA Repair Genes in Endometrial Cancer
}

\author{
Anna Sobczuk • Tomasz Poplawski • Janusz Blasiak
}

Received: 22 March 2012 / Accepted: 12 April 2012 /Published online: 28 April 2012

(C) The Author(s) 2012. This article is published with open access at Springerlink.com

\begin{abstract}
Endometrial cancer belongs to the commonest malignancy in females. Its development may be associated with the high exposure of endometrium to exo- and endogenous estrogens. Estrogens produce DNA bulky adducts and oxidative base damages which are removed in nucleotide excision repair (NER) and base excision repair (BER) pathways. The reaction of endometrial cells to DNA damage may be crucial for their susceptibility to cancer transformation. This reaction is executed mainly by DNA repair, which can be modulated by the variability in the genes encoding DNA repair proteins. In this report we genotyped 4 polymorphisms of 3 DNA repair genes in 94 endometrial cancer patients and 114 age-matched cancer-free women using RFLP-PCR. The following polymorphisms were studied: p.Arg194Trp, p.Arg399Gln of the XRCCl gene, p.Ser326Cys of the $h O G G 1$ gene and p.Lys751Gln of the $E R C C 2$ gene. We found an association between the $E R C C 2$ $751 \mathrm{Gln}$ variant and endometrial cancer occurrence (OR 3.95; $95 \%$ CI 1.88-8.31). Gene-gene interaction between the ERCC2 $751 \mathrm{Gln}$ and XRCC1 194Trp variants also increased the risk of endometrial cancer (OR 4.41; $95 \%$ CI 2.01-9.67). The risk in the carriers of the ERCC2 $751 \mathrm{Gln}$ variant was increased by a positive cancer history in first degree relatives (OR 4.97; $95 \%$ CI 1.98-12.48). The risk of endometrial cancer was not alter by polymorphism
\end{abstract}

\footnotetext{
A. Sobczuk

Department of Gynaecology and Obstetrics,

Medical University of Lodz,

Lodz, Poland

\author{
A. Sobczuk \\ Gynaecology and Oncology Clinic, \\ Polish Mother's Memorial Institute, \\ Lodz, Poland \\ T. Poplawski $\cdot$ J. Blasiak $(\bowtie)$ \\ Department of Molecular Genetics, University of Lodz, \\ Lodz, Poland \\ e-mail: jblasiak@biol.uni.lodz.pl
}

p.Ser326Cys of the hOGG1 gene. The 751 Lys/Gln polymorphism of the ERCC2 gene may be linked with endometrial cancer occurrence and its effect can be potentiated by variants of the $X R C C 1$ gene or first degree relatives positive cancer history.

Keywords XRCC1 $\cdot$ ERCC2 $\cdot$ hOGG1 $\cdot$ Endometrial cancer $\cdot$ RFLP-PCR $\cdot$ BER $\cdot$ NER

\section{Introduction}

Endometrial carcinoma (EC) is the most common tumor of the female genital tract in the Western world [1]. The great majority of EC cases are type I (estrogen-related), frequently showing microsatellite instability and mutations in the PTEN, PIK3CA, K-Ras and $\beta$-catenin genes. These mutations may reflect the genomic instability which is most common symptom of the cancer cells $[2,3]$. This instability may be caused by a continuous exposure to genotoxic stress, including that evoked by estrogens, which can induce bulky DNA adducts and minor modifications to the DNA bases [4]. These lesions are removed by nucleotide and base excision repair (NER and BER), respectively. NER includes recognition of DNA damage by the RAD23B-XPC complex, followed by binding of the XPA/RPA dimer to the lesion. XPA is an important factor for accurate positioning of the ERCC1-ERCC4 (XPF) endonuclease. Two helicases ERCC3 (XPB) and ERCC2 (XPD) are responsible for unwinding the DNA helix, and the ERCC5 (XPG) and ERCC1-ERCC4 nucleases excise a single stranded DNA fragment containing the lesion. The remained gap is filled by DNA polymerase $\delta / \varepsilon$ and DNA ligase I using the intact strand as a template. The base excision repair (BER) pathway corrects most base modifications caused by reactive oxygen species (ROS). A damaged base is recognized by a specific glycosylase, which cleaves the bond between the 
base and sugar, creating an abasic site, which is cleaved by an endonuclease. Resulting gap is filled by pol $\beta$ and the remaining nick is sealed by DNA ligase LIG1 or LIG3 complexed with XRCC1.

Because NER and BER are involved in removing a substantial number of DNA damages, which can contribute to the genome instability, it is reasonable to check whether variability in the genes coding for BER and NER products may be associated with EC. In the present work we searched for an association between EC and the variants of single nucleotide polymorphisms (SNPs) of the BER/NER genes: ERCC2, OGG1 and XRCC1. We studied 4 SNPs occurring in 3 BER and NER genes: p.Arg194Trp, p.Arg399Gln of the XRCC1 gene, p.Ser326Cys of the hOGG1 gene and p.Lys751Gln of the ERCC2 gene (rs1799782, rs25487, rs1052133 and rs13181 respectively). These polymorphisms have been correlated with various tumors, including lung, breast and skin cancers [5-13], but little is known about their association with EC.

\section{Materials and Methods}

Patients

Blood was obtained from 94 women (median age 48 years and median BMI 28) with EC treated in 2004-2006 at the Polish Mother's Memorial Hospital (Lodz, Poland). All patients had histologically confirmed EC and agreed to complete a risk factor questionnaire. The characteristics of the subjects enrolled in this study are presented in Table 1. Control samples consisted of DNA extracted from blood cells from age-matched 114 cancer-free women. The study was approved by the Local Ethic Committee and each patient gave a written consent.

\section{Genotype Determination}

Genomic DNA was prepared using GeneMatrix Blood DNA purification Kit (EURx, Gdansk, Poland) according to the manufacturer instruction. Genotypes were determined by PCR-RFLP (polymerase chain reaction-restriction fragment length polymorphism). Genome regions that include studied polymorphisms were amplified by PCR using primers listed in Table 2. The PCR reaction (total volume $25 \mu \mathrm{l}$ ) was launched with a mixture containing $100 \mathrm{ng}$ genomic DNA, $5 \mathrm{mM}$ dNTPs, 5 pmol each primer and $1 \mathrm{U}$ Taq DNA polymerase (Biotools, Madrid, Spain) which was added into PCR buffer containing $10 \mu \mathrm{mM}$ Tris- $\mathrm{HCl}, 1.5 \mu \mathrm{M} \mathrm{MgCl}{ }_{2}$ and $50 \mathrm{mM} \mathrm{KCl}$. PCR conditions were as follows: initial denaturation step at $95{ }^{\circ} \mathrm{C}$ for $5 \mathrm{~min}, 30$ cycles at $95{ }^{\circ} \mathrm{C}$ for $30 \mathrm{~s}$ and $30 \mathrm{~s}$ at the $62{ }^{\circ} \mathrm{C}$ annealing temperature, and at $72{ }^{\circ} \mathrm{C}$ for $30 \mathrm{~s}$. The final extension step was performed at
Table 1 Characteristics of the study population

\begin{tabular}{|c|c|c|}
\hline Characteristics & Cases $(n=94)$ & Controls $(n=114)$ \\
\hline \multicolumn{3}{|l|}{ Age (y) } \\
\hline Mean & 61 & 55 \\
\hline Min & 43 & 45 \\
\hline Max & 83 & 84 \\
\hline \multicolumn{3}{|l|}{ Education } \\
\hline Elementary school & 21 & 22 \\
\hline Secondary technical school & 15 & 15 \\
\hline High school & 38 & 50 \\
\hline More than high school & 20 & 27 \\
\hline \multicolumn{3}{|l|}{ No. of birds } \\
\hline 0 & 14 & 19 \\
\hline 1 & 28 & 22 \\
\hline$>1$ & 52 & 73 \\
\hline \multicolumn{3}{|l|}{ Body mass index } \\
\hline$<19$ & 0 & 0 \\
\hline $18-25$ & 25 & 37 \\
\hline $26-29$ & 40 & 50 \\
\hline$>30$ & 29 & 27 \\
\hline \multicolumn{3}{|l|}{ First menarche } \\
\hline Before 11 years & 5 & 10 \\
\hline $12-13$ years & 35 & 56 \\
\hline $14-15$ years & 43 & 30 \\
\hline After 16 years & 9 & 11 \\
\hline Missing & 2 & 7 \\
\hline \multicolumn{3}{|l|}{ Hypertension } \\
\hline & 51 & 43 \\
\hline \multicolumn{3}{|l|}{ HRT } \\
\hline Yes & 15 & 31 \\
\hline No & 79 & 74 \\
\hline Missing & 0 & 9 \\
\hline \multicolumn{3}{|l|}{ Smoking } \\
\hline No & 64 & 73 \\
\hline Past or Current & 26 & 36 \\
\hline Missing & 4 & 5 \\
\hline \multicolumn{3}{|l|}{ Alcohol consumption } \\
\hline Yes & 49 & 69 \\
\hline No & 43 & 39 \\
\hline Missing & 4 & 6 \\
\hline \multicolumn{3}{|l|}{ Family cancer } \\
\hline Yes & 29 & 19 \\
\hline No & 63 & 84 \\
\hline Missing & 4 & 11 \\
\hline \multicolumn{3}{|l|}{ FIGO stage } \\
\hline I & 71 & \\
\hline II & 8 & \\
\hline III & 13 & \\
\hline IV & 2 & \\
\hline \multicolumn{3}{|l|}{ FIGO grade } \\
\hline G1 & 41 & \\
\hline G2 & 28 & \\
\hline G3 & 25 & \\
\hline
\end{tabular}


Table 2 Primers used to analyze p.Arg194Trp, p.Arg399Gln polymorphisms of the $X R C C 1$ gene, p.Ser326Cys polymorphism of the hOGG1 and p.Lys751Gln polymorphism of the $E R C C 2$ gene

\begin{tabular}{|c|c|c|}
\hline Gene & Polymorphism & Primers \\
\hline \multirow[t]{4}{*}{$X R C C 1$} & \multirow[t]{2}{*}{ p.Arg194Trp } & forward 5'-GCCCGTCCCAGGTA-3' \\
\hline & & reverse 5'-AGCCCCAAGACCCTTTCACT-3' \\
\hline & \multirow[t]{2}{*}{ p.Arg399Gln } & forward 5'-CAAGTACAGCCAGGTCCTAG-3' \\
\hline & & reverse 5'-CCTTCCCTCTGGAGTAC-3' \\
\hline \multirow[t]{2}{*}{$h O G G 1$} & \multirow[t]{2}{*}{ p.Ser326Cys } & forward 5'-GGAAGGTGCTTGGGGAAT-3' \\
\hline & & reverse 5'-ACTGTCACTAGTCTCACCAG-3' \\
\hline \multirow[t]{2}{*}{ ERCC2 } & \multirow[t]{2}{*}{ p.Lys $751 \mathrm{Gln}$} & forward 5'-CTGCTCAGCCTGGAGCAGC-3' \\
\hline & & reverse 5'-TAGAATCAGAGAGAGGAGACGCTG-3'. \\
\hline
\end{tabular}

$72{ }^{\circ} \mathrm{C}$ for $5 \mathrm{~min}$. The PCR was carried out in a MJ Research, INC thermal cycler, model PTC-100 (Waltham, MA, USA). Following PCR, $20 \mathrm{ml}$ aliquots were removed and subjected to restriction digestion with $P v u I I$ (for codon 194), BcnI (for codon 399), SatI (for codon 326) or PstI (for codon 751). All restriction enzymes were from Fermentas, Vilnius, Lithuania). The digested products were resolved on a $8 \%$ acrylamide gel and stained with $0.5 \mu \mathrm{g} / \mathrm{ml}$ ethidium bromide. The cleavage of the XRCC1 fragment with $P v u$ II produced bands of 292/174/21,313/292/174/21 and 313/174 bp corresponding to the Arg/Arg, Arg/Trp and Trp/Trp genotypes, respectively. The $B c n \mathrm{I}$ restrictase having acted on the same fragment produced bands of 159/89, 248/159/89 and 248 bp corresponding to the 399 Arg/Arg, Arg/Gln and Gln/ Gln genotypes, respectively. The SatI restriction enzyme yielded products of 200,200/100/100 and $100 \mathrm{bp}$ corresponding to the Ser/Ser, Ser/Cys and Cys/Cys genotypes of the OGG1 gene, respectively. The cleavage with Pst I produced fragments of 161, 161/120/41 and 120/41 bp corresponding to the Lys/Lys, Lys/Gln and Gln/Gln genotypes of the ERCC2 gene, respectively.

\section{Data Analysis}

Logistic regression analysis was used to compute odds ratio (OR) and associated $95 \%$ confidence interval (95\% CI) relating each of the SNPs as well as combinations of SNPs and another analysed factors presented in Table 1 to the risk of EC. Only matching variables and factors that altered the ORs by $10 \%$ were included in the final multivariate models.
Analyses were performed using STATISTICA 10 package (Statsoft, Tulsa, OK, USA).

\section{Results}

All distributions of genotypes did not differ significantly ( $p$ $<0.05$ ) from those expected by the Hardy-Weinberg equilibrium. An association (OR 3.95; 95 \% CI 1.88-8.31) was found between the $\mathrm{Gln} / \mathrm{Gln}$ genotype of the p.Lys $751 \mathrm{Gln}$ polymorphism of ERCC2 gene and EC occurrence (Table 3). There were no differences in the genotype distributions between cancer patients and controls for the remaining polymorphisms (Tables 4, 5 and 6). We also analyzed combined genotype of all polymorphism pairs. The Arg/Arg genotype of the XRCC1 gene increased the risk of EC for the carriers of the $751 \mathrm{Gln} / \mathrm{Gln}$ variant of the ERCC2 gene (Table 7). We also found that the Cys/Cys and Arg/Arg genotypes of the p.Ser326Cys polymorphism of the $h O G G 1$ gene and the Arg/Gln genotype of the XRCC1 gene decreased EC risk (OR 0.50; 95 \% CI 0.25-0.99) (Table 8). No difference between genotype distributions was found for others combined genotypes of the polymorphisms (data not shown). Adjustment for first degree relatives cancer history increased OR for the Gln/Gln genotype of the p.Lys $751 \mathrm{Gln}$ polymorphism of ERCC2 gene from OR 3.95; $95 \% \mathrm{CI}$ 1.88-8.31 to OR 4.97; $95 \%$ CI $1.98-12.48$. Other remaining confounders, including postmenopausal hormone use and body mass index, did not modify the observed estimates of association.
Table 3 The allele and genotype frequency and odds ratio (OR) of p.Lys751Gln polymorphism of the $E R C C 2$ gene in endometrial cancer

\begin{tabular}{lllllll}
\hline \multirow{2}{*}{ Genotype or Allele } & \multicolumn{2}{l}{ Patients $(n=94)$} & & \multicolumn{2}{l}{ Controls $(n=114)$} & \\
\cline { 2 - 3 } Lys/Lys & Number & Frequency & & Number & Frequency & \multirow{2}{*}{ OR (95 \% CI) } \\
\hline Lys/Gln & 30 & 0.32 & & 38 & 0.33 & $0.93(0.52-1.67)$ \\
Gln/Gln & 36 & 0.38 & & 64 & 0.56 & $0.48(0.27-0.84)$ \\
Lys & 28 & 0.30 & & 12 & 0.11 & $3.95(1.88-8,31)$ \\
Gln & 96 & 0.52 & & 140 & 0.61 & $0.65(0.44-0.96)$ \\
\hline
\end{tabular}


Table 4 The allele and genotype frequency and odds ratio (OR) of the p.Ser326Cys polymorphism of the $h O G G 1$ gene in endometrial cancer

\begin{tabular}{lcccccc}
\hline & \multicolumn{2}{l}{ Patients $(n=94)$} & & \multicolumn{2}{l}{ Controls $(n=114)$} & \\
\cline { 2 - 3 } Genotype or Allele & Number & Frequency & & Number & Frequency nn & OR (95 \% CI) \\
\hline Ser/Ser & 64 & 0.68 & & 83 & 0.73 & $0.79(0.43-1.44)$ \\
Ser/Cys & 23 & 0.24 & & 28 & 0.24 & $0.99(0.52-1.87)$ \\
Cys/Cys & 7 & 0.07 & & 3 & 0.02 & $2.97(0.74-11.84)$ \\
Ser & 151 & 0.82 & & 194 & 0.85 & $0.71(0.42-1.19)$ \\
Cys & 37 & 0.18 & & 34 & 0.15 & $1.39(0.83-2.33)$ \\
\hline
\end{tabular}

\section{Discussion}

In the present study we genotyped four common polymorphisms of the XRCC1, hOGG1 and ERCC2 DNA repair genes and tested the association between the distributions of their genotypes with EC. These polymorphisms have been shown to have functional significance and may be in part responsible, for the inter-individual difference in capacity of DNA repair in the general population and for low DNA repair efficacy in cancer patients [5-7, 14-17]. We obtained a significantly higher OR than for other analyzed polymorphisms, odds ratio for the Gln/Gln genotype of the p.Lys751Gln polymorphism of the ERCC2 gene than for genotypes of remaining polymorphisms. The protein encoded by the ERCC2 gene is involved in transcriptioncoupled NER and is an important member of the basal transcription factor TFIIH. Exchange of 751 Lys for Gln in the ERCC2 can lead to a conformational change in the encoded protein at the domain of the interaction between ERCC2 and its helicase activator, p44, inside the TFIIH complex [18]. The Gln/Gln variant of the ERCC2 gene has been associated with an increased risk of lung cancer [10, 11], and correlated with higher risk of skin, bladder and breast cancer $[12,19,20]$. Surprisingly, this polymorphism has been also linked with non-cancer diseases, such as cataract [21]. To date, none studies have addressed the association between alterations in this region of the ERCC2 gene and EC. Because a proper functioning of the ERCC2 gene is important for the genomic stability, its alternations may be associated with a higher cancer susceptibility.
Type I EC are estrogen-related. The mechanisms by which estrogens might cause the development of EC remain unclear. Estrogens have the unique chemical structure that distinguish them from other groups of hormones and their metabolism in eukaryotic cells include formation of a variety of intermediate forms and production of ROS. Estrogens undertake oxidative metabolism through hydroxylation pathway, but the major intermediates are $2-\mathrm{OH}$ and $4-\mathrm{OH}$ estrogens [22]. These chemicals are further oxidized to semiquinones and quinones, which may form bulky DNA adducts and may undergo redox cycling, producing ROS that may cause oxidative stress, lipid peroxidation, and DNA damage [23, 24]. Consequently, estrogen metabolism in human cells may play a role in tumor initiation via direct damage to the DNA by the formation of bulky DNA adducts and/or by producing ROS that cause oxidative DNA damage. These types of DNA damage are usually repaired by NER and BER.

In our study we analyzed the association between three polymorphisms of two genes of BER and EC. We did not find any association when we analyzed each polymorphism separately, but the analysis of combined genotypes showed that they might significantly increase the risk of EC. The results obtained suggest that polymorphisms of the XRCC1 and $E R C C 2$ genes may modulate the risk and therefore play a role in the etiology of EC. The XRCC1 protein has no known catalytic activity but serves to orchestrate BER through its role as a central scaffolding protein for DNA ligase III, DNA polymerase $\beta$, and poly(ADP-ribose) polymerase (PARP) [25]. Arg/Trp variant of the p.Arg/Trp
Table 5 The allele and genotype frequency and odds ratio (OR) of the p.Arg399Gln polymorphism of the XRCCl gene in endometrial cancer

\begin{tabular}{lllllll}
\hline & \multicolumn{2}{l}{ Patients $(n=94)$} & & \multicolumn{2}{l}{ Controls $(n=114)$} & \\
\cline { 2 - 3 } Genotype or Allele & Number & Frequency & & Number & Frequency nn & OR (95 \% CI) \\
\hline Arg/Arg & 27 & 0.29 & & 43 & 0.37 & $0.66(0.37-1.19)$ \\
Arg/Gln & 45 & 0.48 & & 48 & 0.42 & $1.22(0.72-2.18)$ \\
Gln/Gln & 22 & 0.23 & & 23 & 0.21 & $1.21(0.62-2.34)$ \\
Arg & 99 & 0.53 & & 134 & 0.58 & $0.78(0.52-1.15)$ \\
Gln & 89 & 0.47 & & 94 & 0.42 & $1.28(0.86-1.89)$ \\
\hline
\end{tabular}


Table 6 The allele and genotype frequency and odds ratio (OR) of the p.Arg 194Trp polymorphism of the XRCCl gene in endometrial cancer

\begin{tabular}{|c|c|c|c|c|c|}
\hline \multirow[b]{2}{*}{ Genotype or Allele } & \multicolumn{2}{|c|}{ Patients $(n=94)$} & \multicolumn{2}{|c|}{ Controls $(n=114)$} & \multirow[b]{2}{*}{ OR $(95 \% \mathrm{CI})$} \\
\hline & Number & Frequency & Number & Frequency & \\
\hline Arg/Arg & 89 & 0.95 & 103 & 0.90 & $1.90(0.64-5.67)$ \\
\hline Arg/Trp & 5 & 0.05 & 11 & 0.10 & $0.53(0.17-1.57)$ \\
\hline $\operatorname{Trp} / \operatorname{Trp}$ & 0 & - & 0 & - & - \\
\hline Arg & 183 & 0.97 & 217 & 0.95 & $1.85(0.63-5.43)$ \\
\hline Trp & 5 & 0.03 & 11 & 0.05 & $0.50(0.18-1.57)$ \\
\hline
\end{tabular}

Table 7 The distribution of combined genotypes of the of the p.Arg194Trp polymorphism of the XRCC1 gene and p.Lys571Gln polymorphism of the $E R C C 2$ gene in endometrial cancer

\begin{tabular}{|c|c|c|c|c|c|}
\hline \multirow[b]{2}{*}{ Genotype or Allele } & \multicolumn{2}{|c|}{ Patients $(n=94)$} & \multicolumn{2}{|c|}{ Controls $(n=114)$} & \multirow[b]{2}{*}{ OR $(95 \% \mathrm{CI})$} \\
\hline & Number & Frequency & Number & Frequency & \\
\hline Arg/Arg - Lys/Lys & 28 & 0.30 & 36 & 0.31 & $0.92(0.51-1.66)$ \\
\hline Arg/Arg - Lys/Gln & 33 & 0.35 & 57 & 0.50 & $0.54(0.31-0.95)$ \\
\hline $\operatorname{Arg} / \operatorname{Arg}-\mathrm{Gln} / \mathrm{Gln}$ & 28 & 0.30 & 10 & 0.09 & $4.41(2.01-9.67)$ \\
\hline Arg/Trp - Lys/Lys & 2 & 0.02 & 2 & 0.02 & $1.21(0.16-8.81)$ \\
\hline Arg/Trp - Lys/Gln & 3 & 0.03 & 7 & 0.06 & $0.49(0.12-1.96)$ \\
\hline $\operatorname{Arg} / \operatorname{Trp}-\mathrm{Gln} / \mathrm{Gln}$ & 0 & - & 2 & 0.02 & - \\
\hline Trp/Trp - Lys/Lys & 0 & - & 0 & - & - \\
\hline Trp/Trp - Lys/Gln & 0 & - & 0 & - & - \\
\hline $\operatorname{Trp} / \operatorname{Trp}-\mathrm{Gln} / \mathrm{Gln}$ & 0 & - & 0 & - & - \\
\hline
\end{tabular}

polymorphism of the XRCC1 gene occurs in proliferating cell nuclear antigen binding region, but few studies have examined the influence of the Trp/Trp genotype of this polymorphism on the function of the XRCC1 protein [26, 27]. This variant has been associated with a lower bleomycin and benzo(a)pyrene diol-epoxide sensitivity in vitro [16, 28]. These data suggest a protective role of the $\operatorname{Trp} / \operatorname{Trp}$ genotype of the p.Arg/Trp polymorphism of the XRCC1 gene against the development of cancer and this function can be underlined by increasing the activity of BER. This is in agreement with our result suggesting a potential role of the Arg/Arg genotype of the p.Arg/Trp polymorphism of the $X R C C 1$ gene with reduced BER capacity as compared with $\operatorname{Trp} / \operatorname{Trp}$ genotype in EC.

We have also found that cancer history in first degree relatives increased endometrial cancer risk in the $\mathrm{Gln} / \mathrm{Gln}$ variant of the p.Lys751Gln polymorphism of the ERCC2 gene. This result may suggest hereditary background of EC cancer and/or major contribution of the p.Lys $751 \mathrm{Gln}$ polymorphism of the ERCC2 gene in cancer development but more studies performed on larger population is needed to draw a final conclusion.
Table 8 The distribution of combined genotypes of the p.Ser326Cys polymorphism of the $h O G G 1$ gene and p.Arg399Gln polymorphism of the $X R C C 1$ gene in endometrial cancer

\begin{tabular}{|c|c|c|c|c|c|}
\hline \multirow[b]{2}{*}{ Genotype or Allele } & \multicolumn{2}{|c|}{ Patients $(n=94)$} & \multicolumn{2}{|c|}{ Controls $(n=114)$} & \multirow[b]{2}{*}{ OR $(95 \% \mathrm{CI})$} \\
\hline & Number & Frequency & Number & Frequency & \\
\hline Ser/Ser - Arg/Arg & 16 & 0.17 & 33 & 0.29 & $0.50(0.25-0.99)$ \\
\hline Ser/Ser - Arg/Gln & 30 & 0.32 & 34 & 0.30 & $1.10(0.61-1.99)$ \\
\hline Ser/Ser - Gln/Gln & 18 & 0.19 & 16 & 0.14 & $1.45(0.69-3.01)$ \\
\hline Ser/Cys - Arg/Arg & 9 & 0.10 & 9 & 0.08 & $1.23(0.47-3.25)$ \\
\hline Ser/Cys - Arg/Gln & 12 & 0.13 & 12 & 0.10 & $1.24(0.53-2.91)$ \\
\hline Ser/Cys - Gln/Gln & 2 & 0.02 & 7 & 0.06 & $0.33(0.06-1.63)$ \\
\hline Cys/Cys - Arg/Arg & 2 & 0.02 & 1 & 0.01 & $2.45(0.21-27.52)$ \\
\hline Cys/Cys - Arg/Gln & 3 & 0.03 & 2 & 0.02 & $1.85(0.32-11.28)$ \\
\hline Cys/Cys - Gln/Gln & 2 & 0.02 & 0 & - & - \\
\hline
\end{tabular}


In summary, our results suggest that the $751 \mathrm{Gln} / \mathrm{Gln}$ variant of the p.Lys $751 \mathrm{Gln}$ polymorphism of the ERCC2 gene can be associated with the occurrence of EC. We have also showed that the Arg/Arg variant of the p. Arg194Trp polymorphism of the XRCC1 gene increased the risk of EC in individuals with the Gln/Gln variant of the ERCC2 gene. The data obtained suggest also that positive cancer history in first degree relatives in connection with $\mathrm{Gln} / \mathrm{Gln}$ variant of the p.Lys $751 \mathrm{Gln}$ polymorphism of the ERCC2 gene may be associated with EC.

Acknowledgments This work was supported by the grant 505/376 and 505/377 from University of Lodz.

Open Access This article is distributed under the terms of the Creative Commons Attribution License which permits any use, distribution, and reproduction in any medium, provided the original author(s) and the source are credited.

\section{References}

1. Prat J, Gallardo A, Cuatrecasas M, Catasus L (2007) Endometrial carcinoma: pathology and genetics. Pathology 39:72-87

2. Oda K, Stokoe D, Taketani Y, McCormick F (2005) High frequency of coexistent mutations of PIK3CA and PTEN genes in endometrial carcinoma. Cancer Res 65:10669-10673

3. Velasco A, Bussaglia E, Pallares J et al (2006) PIK3CA gene mutations in endometrial carcinoma: correlation with PTEN and K-RAS alterations. Hum Pathol 37:1465-1472

4. Liehr JG, Fang WF, Sirbasku DA, Ari-Ulubelen A (1986) Carcinogenicity of catechol estrogens in Syrian hamsters. J Steroid Biochem 24:353-356

5. Kohno T, Kunitoh H, Toyama K et al (2006) Association of the OGG1-Ser326Cys polymorphism with lung adenocarcinoma risk. Cancer Sci 97:724-728

6. Pachouri SS, Sobti RC, Kaur P, Singh J (2007) Contrasting impact of DNA repair gene XRCC1 polymorphisms Arg399Gln and Arg194Trp on the risk of lung cancer in the north-Indian population. DNA Cell Biol 26:186-191

7. Poplawski T, Arabski M, Kozirowska D et al (2006) DNA damage and repair in gastric cancer-a correlation with the hOGG1 and RAD51 genes polymorphisms. Mutat Res 601:83-91

8. Yin J, Vogel U, Ma Y, Qi R, Sun Z, Wang H (2007) The DNA repair gene XRCC1 and genetic susceptibility of lung cancer in a northeastern Chinese population. Lung Cancer 56:153-160

9. Hatt L, Loft S, Risom L et al (2008) OGG1 expression and OGG1 Ser326Cys polymorphism and risk of lung cancer in a prospective study. Mutat Res 639:45-54

10. Yin J, Vogel U, Ma Y, Guo L, Wang H, Qi R (2006) Polymorphism of the DNA repair gene ERCC2 Lys751Gln and risk of lung cancer in a northeastern Chinese population. Cancer Genet Cytogenet 169:27-32

11. De Ruyck K, Szaumkessel M, De Rudder I et al (2007) Polymorphisms in base-excision repair and nucleotide-excision repair genes in relation to lung cancer risk. Mutat Res 631:101-110

12. Brewster AM, Jorgensen TJ, Ruczinski I et al (2006) Polymorphisms of the DNA repair genes ERCC2 (Lys751Gln) and XRCC1
(Arg399Gln and Arg194Trp): relationship to breast cancer risk and familial predisposition to breast cancer. Breast Cancer Res Treat 95:73-80

13. Patel AV, Calle EE, Pavluck AL, Feigelson HS, Thun MJ, Rodriguez C (2005) A prospective study of XRCC1 (X-ray crosscomplementing group 1) polymorphisms and breast cancer risk. Breast Cancer Res 7:1168-1173

14. Abdel-Rahman SZ, El-Zein RA (2000) The 399Gln polymorphism in the DNA repair gene XRCC1 modulates the genotoxic response induced in human lymphocytes by the tobacco-specific nitrosamine NNK. Cancer Lett 159:63-71

15. Vodicka P, Stetina R, Polakova V et al (2007) Association of DNA repair polymorphisms with DNA repair functional outcomes in healthy human subjects. Carcinogenesis 28:657664

16. Wang Y, Spitz MR, Zhu Y, Dong Q, Shete S, Wu X (2003) From genotype to phenotype: correlating XRCC1 polymorphisms with mutagen sensitivity. DNA Repair 2:901-908

17. Silva SN, Moita R, Azevedo AP et al (2007) Menopausal age and $\mathrm{XRCC} 1$ gene polymorphisms: role in breast cancer risk. Cancer Detect Prev 31:303-309

18. Fan L, Fuss JO, Cheng QJ, Arvai AS, Hammel M, Roberts VA, Cooper PK, Tainer JA (2008) XPD helicase structures and activities: insights into the cancer and aging phenotypes from XPD mutations. Cell 133:789-800

19. Stern MC, Conway K, Li Y, Mistry K, Taylor JA (2006) DNA repair gene polymorphisms and probability of TP53 mutation in bladder cancer. Mol Carcinog 45:715-719

20. Applebaum KM, Karagas MR, Hunter DJ et al (2007) Polymorphisms in nucleotide excision repair genes, arsenic exposure, and non-melanoma skin cancer in New Hampshire. Environ Health Perspect 115:1231-1236

21. Unal M, Guven M, Batar B, Ozaydin A, Sarici A, Devranoglu K (2007) Polymorphisms of DNA repair genes ERCC2 and XRCC1 and risk of cataract development. Exp Eye Res $85: 328-334$

22. Martucci CP, Fishman J (1993) P450 enzymes of estrogen metabolism. Pharmacol Ther 57:237-257

23. Stack DE, Byun J, Gross ML, Rogan EG, Cavalieri EL (1996) Molecular characteristics of catechol estrogen quinones in reactions with deoxyribonucleosides. Chem Res Toxicol 9:851-859

24. Dwivedy I, Devanesan P, Cremonesi P, Rogan E, Cavalieri E (1992) Synthesis and characterization of estrogen 2,3- and 3,4quinones. Comparison of DNA adducts formed by the quinones versus horseradish peroxidase-activated catechol estrogens. Chem Res Toxicol 5:828-833

25. Moser J, Kool H, Giakzidis I, Caldecott K, Mullenders LH, Fousteri MI (2007) Sealing of chromosomal DNA nicks during nucleotide excision repair requires XRCC1 and DNA ligase III alpha in a cellcycle-specific manner. Mol Cell 27:311-323

26. Mortusewicz O, Leonhardt H (2007) XRCC1 and PCNA are loading platforms with distinct kinetic properties and different capacities to respond to multiple DNA lesions. BMC Mol Biol $8: 81$

27. Fan J, Otterlei M, Wong HK, Tomkinson AE, Wilson DM 3rd (2004) XRCC1 co-localizes and physically interacts with PCNA. Nucleic Acids Res 32:2193-2201

28. Tuimala J, Szekely G, Gundy S, Hirvonen A, Norppa H (2002) Genetic polymorphisms of DNA repair and xenobioticmetabolizing enzymes: role in mutagen sensitivity. Carcinogenesis 23:1003-1008 